能を更に高めるためには, 胃チューブを用いて, 胃液や 粘液等を積極的に排除する方法の活用が望まれる，以上 の(1)〜(4)まで結論としてあげておられたが，胃X線検查 に携わる放射線技師にとって装置面での改良, 研究と並 行して，このような撮影手技面での技師の立場からの研 究も今後積み重ねていく必要があると感じた. 検診の胸 部写真では, 有効照射野内の概存構造が全て描出される ことが望ましいが，縦隔の描出がむずかしい，このよう にX線吸収が非常に異なる部位を一回だけのX線曝射で 写真全域を診断しやすい適正な濃度, コントラストにす るため, 感度補償方法を被曝線量と併せて検討された。 結果はどの方法も一長一短があるが, 同時二枚撮り法が 画像特性，および臨床写真（10枚）での内科医師による 写真評洒では有用という結論であったが，この方法は二 枚のフィルムを使用するのでコスト高になるという難点 がある. 今後全下肢, 全脊柱撮影等をはじめとして腹部 単純撮影の側腹壁部, 腰椎側面撮影の第 5 腰椎から仙骨 までの濃度調整等, 古くて新しい問題として今後検討課 題は多いと思われる.

超音波

座長 中島義明 (姫路循環器)

\section{2. 超音波による胆石の種類判別の検討（胆石の質的診} 断)

兵庫県立加古川病院放射線科 水谷正弘

(神戸腹部研究会)

〔目的〕胆石の質的診断である種類判別の可能性につ いて超音波により検討したので報告する．

〔方法〕当院で胆摘術を施行した症例についてUS 像 を retrospectiveに検討した. US 像は，4 typeに分類 し, 胆石は 5 種類に分類した。

〔結果〕コレステロール系石は，I・II型を示す胆石 が83\%で，色素系石は，III・IV型を示す胆石が78\%であ り，コ系石と色素系石の判別は可能と思われる。しかし US 像は胆石の割面構造，成分等をかなり良く反映する ため，これらが似た胆石の鑑別は困難と思われる。

胆石溶解療法については，II型を示す症例が適応とな ると考えられる。

13. 超音波用透明ボーラス（BOLX-II）と超音波画像に วいて

\section{大阪大学病院中央放射線部}

○森口武彦・川原雅昭・森 嘉信

〔目的〕探触子は $3.5 と 5 \mathrm{MHz}$ のリニア・スキャン装

置による. カプラとしのボルックスの厚さ $5,10,20 \mathrm{~mm}$ を使用したときの, 体表面に近い表在組織における超音
波画像を検討した。

〔結果〕（1)柔軟性が良く透明に近いので検查部位の確 認がしやすい.（2)任意の形と大きさに加工でき探触子の 圧迫による変形はない.(3)使用後のクリーニングは可能. (4)体表面でのアーチファクトが少ない.（5)厚さによる減 衰の画像は Near Gain を上げ, dynamic range を下げ る. (6)体表面の近くでも焦点領域を選択でき分解能が良 く, $3.5 \mathrm{MHz}$ でも利用できる.(7)厚さ 5 と $10 \mathrm{~mm}$ は適 し, $20 \mathrm{~mm}$ は減衰と多重反射が増加する.

\section{座長集約}

近年, 超音波装置の発展, 進歩により画質が改善され たことにより，検查の適応範囲が拡大されスクリーニン グ，また精密検査として臨床上有用な手段の評価を得て いる. 将来, 超音波検查に関連した業務に従事する会員 も増加すると思われる。

当日の超音波セクションは他会場に比べ, 出席会員数 が少なく寂しい感がするとともに充分な討論を尽くすこ とができなかったのが残念である。

演題 12 は超音波像のパターンより胆石の種類判別を行 った報告である．演者らは胆摘術を施行した症例に対し て視覚的に胆石を 5 種類に，超音波像を 4 種類に分類し 比較した。この発表意義は内科的治療として胆石溶解療 法の適応決定にある。

盟石の超音波像は割面構造，すなわち層構造を反映し ているとし, 判別は可能であるが石灰化の有無等 CT 検 㚗を参考にすることが望ましいとした。

演題13は音響カプラ材 BOLX-IIの報告である。

装置の欠点として近距離は focus 結ぶことが困難で あり，分解能が低下する。すなわちカプラをプローブと 皮膚間に介在させ focus 領域内に目的とする部位を位置 させる方法である，この材質は減衰が少なく生体と音響 特性が近いことが望まれる。

演者らは3.5, $5 \mathrm{MHz}$ に対しカプラ厚と gain を変化さ せ滅衰を調べるとともにファントム, 臨床にて近距離分 解能の向上を確認した。

現在は腹部検查でも視野の桩大にコンベックス，セク 夕方式が多く用いられ，これらにも有効な方法でありい ろんな部位への活用が可能である。

最後に演者ならびに共同研究者の今後の御活躍を期待 します。

RI

座長 紀田 利（姫路循環器病センター）

14. 連続スポットホールボディ方式シンチグラムの基礎 的検討 